\title{
Clothing enterprise marketing channel mode of analysis and research
}

\author{
Yilong Wang \\ Management System, Handan Polytechnic College, Handan, China, 056001 \\ 54892713@163.com
}

Keywords: Clothing enterprises; Marketing channel pattern; Selecting

\begin{abstract}
With the development of the times, all areas of sales model has also been changed, the clothing sector has also been a change and innovative sales channels and modes, multi-stream channel model garment pattern has started to form, the clothing brand enterprises to gradually form a "Direct + join "as the main body, a combination of a variety of marketing channels coexist pattern. The development of multi-channel marketing and development of the garment industry has played a good role in promoting, at the convenience of consumers and also expand the company's sales range. By analyzing the clothing channel mode, the choice of marketing channel mode clothing enterprises makes a statement.
\end{abstract}

\section{Apparel industry marketing model status and apparel products consumption characteristics}

Situation Marketing Channel. With the new retail formats to see innovation, China's apparel business and marketing in changing, in a different place clothing sales, department stores, specialty stores, shopping malls, general stores, supermarkets, wholesale markets, non-store formats are important places clothing sales. According to statistics of the China National Commercial Information Center, as is shown in figure1 China's apparel market table shows the terminal constitutes marketing channels.

\begin{tabular}{|c|c|c|c|}
\hline Sales channels & $\begin{array}{c}\text { Sales(hundred } \\
\text { million) }\end{array}$ & $\begin{array}{c}\text { The proportion of urban } \\
\text { sales\% }\end{array}$ & $\begin{array}{c}\text { The proportion of total } \\
\text { sales }\end{array}$ \\
\hline $\begin{array}{c}\text { Large department } \\
\text { stores }\end{array}$ & 700 & 38 & 27 \\
\hline $\begin{array}{c}\text { Commodity } \\
\text { wholesale market } \\
\text { exclusive shop }\end{array}$ & 800 & 10 & 7.1 \\
\hline general merchandise \\
store
\end{tabular}

Fig.1 China's apparel market table shows the terminal constitutes marketing channels

It can be seen from the table, the large department stores and specialty stores is the main place for consumers to choose and buy goods, but also the pursuit of quality of well-known brand clothing sales over the place general store, warehouse shopping malls, supermarkets and chain stores clothing for sale mainly to middle and low, wholesale clothing market is by the garment enterprises and wholesalers specialize in wholesale and retail clothing site, supported by large wholesale market a variety of individual retail clothing store currently occupies the largest share of the clothing sales in China, at the same time, the market is China's vast rural market and part of the city's low market supply area.

Warehouse shopping malls, supermarkets, chain stores, clothing for sale is to middle and low based, due to the low operating costs, with the price advantage, in recent years, the development of the rapid format, led by the online store, telephone shopping, mail and other non store sales due to 
its convenience and price advantage and become a good supplement of modern retail formats. In addition our country clothing discount shop is also gradually emerging.

Clothing consumption and overall product characteristic itself. Apparel consumption and clothing products characteristic building marketing channels a great influence on the choice of channel models and constraints guiding role in it and in a nutshell proposed general characteristics apparel consumption and clothing products:

Shopping guide staff clothing products are to buy goods, consumers not only on the clothing itself, such as color, workmanship, style fit or not and make comparisons and decisions on shopping environment have certain requirements, you also need well-trained,providing professional information and advice.

On the one hand clothing consumption has a strong seasonal product-season clothing is called "dead stock", its value and price discount, on the other hand, consumption of clothing with a strong tide of time, relative time alone not too strong tide of men suits, the life cycle as short as three to four years.

Clothing consumption is a kind of emotional and rational consumer behavior, the demand for clothing, no longer just to keep warm modesty and other basic functions, more role is to pursue the added value of goods, clothing products can provide hope to meet the spirit, taste, they are eager to express their own clothing personality and taste of the requirements and values.

Apparel industry is a kind of industry with low technology content, which only needs little investment. Based on this reason, there is a wide variety of apparel products.

\section{Analysis apparel marketing model.}

Composition apparel marketing model. In a nutshell, the main marketing channel composed apparel retailers can be divided into: department stores Comprehensive stores Supermarket ordinary clothing.

Upscale department stores more reflected in brand awareness, influence and psychological implied role in secondary consumer customers; store played a face to consumers, to promote the brand image, simplifying the role of purchase; supermarkets on the one hand to provide consumers with great convenience, on the other hand also for price-sensitive consumers to provide an ideal place; and ordinary clothing store was to provide consumers with greater choice

Here's the basic functions of the various retail formats and features and implementation of adaptation to do a more detailed analysis, summarized and compared.

Department store sales Features. Apparel sales are used in the counter sales and self - selling model, the department store of the type of goods is very much, the profit is high. Department store to take a unified pricing and sales, the purchase of clothing can also be returned and shopping guide to help buy, department stores and more in the city center downtown area, it is decorated luxury, it is more than the target population of young people.

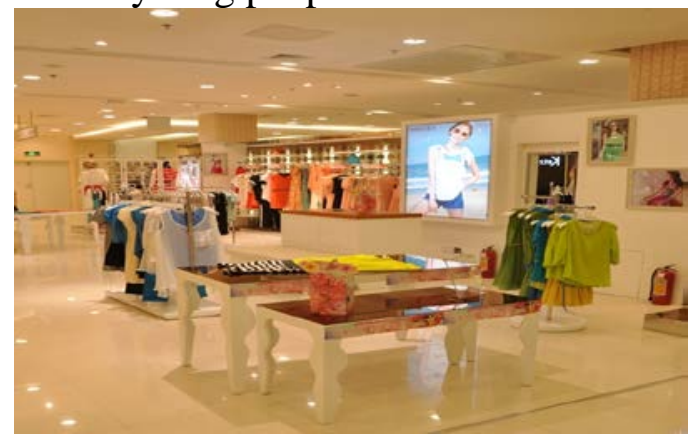

Fig.2 department store

Generally, consumers enter the high-end department store is not price-sensitive consumers, hoping to provide the quality goods to meet, the pursuit of brand value, inappropriate promotion will only damage the brand image, the high-end department stores in general not the implementation of price discounts type of promotional activities, product image is more publicity and comes with high-quality image display products of small gifts, these promotional activities will 
neither destroy the price of the product profit margins, it will not damage the brand image, marketing channel execution function is very good. Upscale department stores tend to have a professional shopping guide personnel and quality assurance, to provide appropriate pre-sale advisory services, sale of return guarantee and sale of ironing, dry cleaning and other services.

The quality, location, value and price of clothing have a decisive influence on the final retail terminal. Under normal circumstances, high-end, high-end clothing more suitable for shopping malls, it is the cause of high, medium and high grade apparel product unit value, coupled with the variety of clothing products, so the demand for large capital of the retailer, the strength of the department store is more capable of financial risk. To buy clothes from the department store, they have a huge economic income, and they have a clear shopping standards.

World-famous brand Pierre $\bullet$ Cardin, crocodiles, Goldlion, Montagut, Versace, etc. into the department store is the ideal choice, on the one hand the famous brand clothing is also often the high-end clothing, with good product adaptation, on the other hand, apparel products easy by imitation and counterfeiting, gross profit rate for these well-known brands, counterfeiting phenomenon is more serious, upscale department stores because of professional procurement staff and a good reputation, to attract consumers real designer clothes, which for counterfeit products also have obvious inhibition.

Upscale department store shoppers are often successful people with higher incomes and good income young people who pursue high quality of life, through the investigation showed that the per capita monthly income of urban households in the middle of the level of consumption in 3000 yuan of young and monthly income of more than 2,000 young people have a clear brand clothing consumption preferences, those surveyed, $92 \%$ of men and 75 percent of women said a clear buy famous or well-known brand preferences. So, the famous or well-known brands to enter the department store, which is the result of consumer behavior and mutual adaptation.

Exclusive shop sales features. Stores have the obligation to maintain and spread the image of clothing brand, the manufacturers have to suit their own clothing brand features, lighting, display requirements, at the same time, manufacturers are required to design and layout of all stores in accordance with the same style, so that the practice of all stores unified and give consumers a unified image, so that they have a strong visual impact, so that the characteristics of brands and products will be displayed, such as retail stores such special retail terminal business philosophy to play the most vividly.As is shown figure 3 exclusive shop.

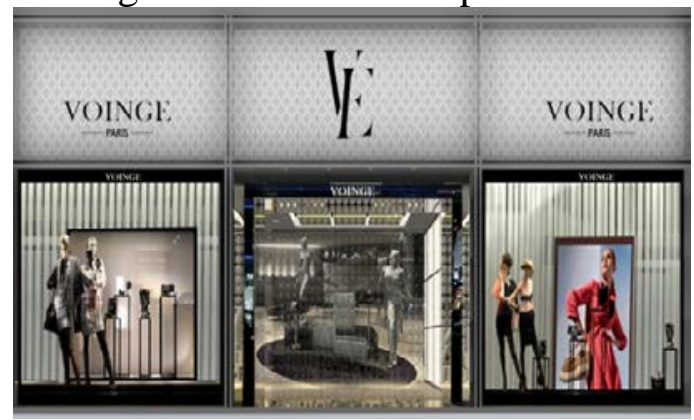

Fig.3 exclusive shop

Visible, compared to other retail mode, the image transmission function performed by the store has a unique and distinct advantage, reflecting the following characteristics: flexibility, diversity, individuality and controllability and uniformity.

Store promotions generally include new product promotion, price discounts, gifts promotions. Through the reasonable promotion can play a promotional product and brand characteristics, attract consumers, resist the effects of competitors and for clothing such as tide of consumer goods, appropriate promotions can be processed in a timely manner, a quarter of goods. Sales promotion to reduce the loss of manufacturers and dealers, increase the turnover rate of capital has a great help.

Clothing style and positioning grasp very accurate, but the store's Purchasing Guide are fully trained to provide professional consulting services to provide after-sales service return and a return visit. With respect to the operation of many brands and products department stores and 
supermarkets and other retail formats, stores can provide more thoughtful, professional, meticulous service.

Optional large stores, store size, style and location of equipment has great flexibility. Store both business value big, expensive products that can also operate in the tens of yuan-priced commodity. From the product range is concerned, can be business casual and formal clothing stores, you can also operate the Recognition and children's clothing stores. Dealer selection considerations and consumer behavior, the famous brand and well-known brands adapted to be sold through retail stores.

General merchandise store sales Features. General merchandise store is a large scale, low cost, high volume, self-service shopping place, it is mainly to appease the consumer to food, daily necessities and a part of consumer goods, such as clothing, home appliances and other retail organization. It is through a large area of display products, easy to buy, low price to attract customers. But the shopping environment and service is not as high-end department stores.

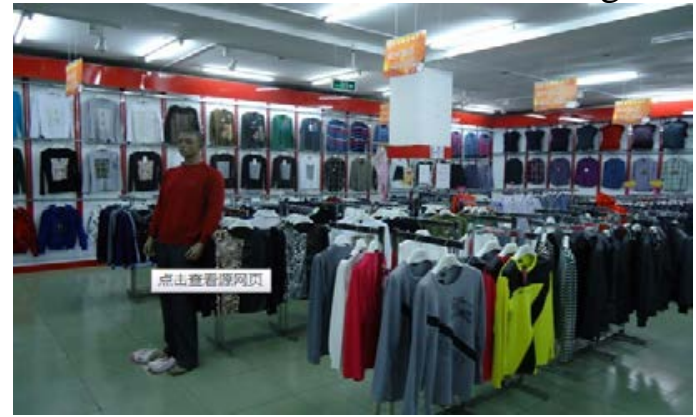

Fig.4 general merchandise store

Supermarkets often based on convenience and low price image in the hearts of the people appear to provide little additional services to meet people's demand for daily fast moving consumer goods, it is characterized by low prices and convenient, simple and self-service.

Since supermarkets often have promotional activities, so the clothing also for promotion, to promote sales, promotional activities and this is sometimes not voluntary garment enterprises. The consequences of this is going to destroy the original stable prices, then raise the original price is difficult;. Excessive discounts harm the brand and product image. Supermarkets to reduce costs, the services provided are limited and more products, customer flow, to the style and needs of each customer to grasp each one clothing are not sufficient, we can not provide professional and thoughtful advice service.

Style supermarket civilians crowded and noisy environment, providing daily FMCG provide limited services. It determines the supermarket business for affordable, low-end clothing, not suitable for operating high-end, high-end clothing.

Through the 100 valid questionnaires analysis results are shown figure (the horizontal axis represents apparel categories, and the vertical axis represents a survey of 100 people by that supermarkets sell this kind of clothing for visitors).As is shown figure 5 general merchandise store fit to buy.

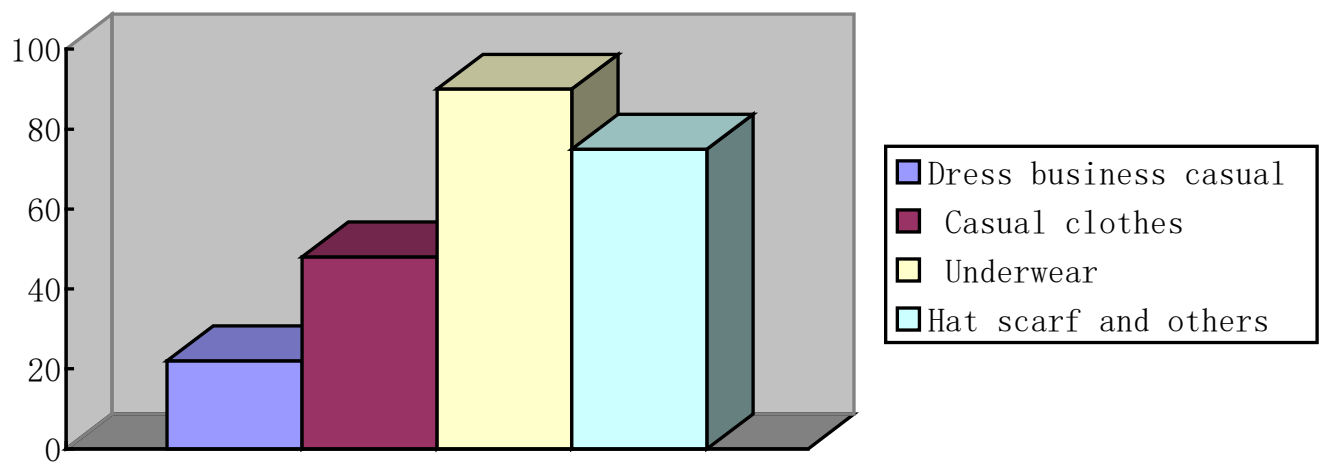

Fig.5 general merchandise store fit to buy 
Supermarkets pale in the product image transmission function, determines that it is not for the sale of well-known brands and well-known brand; supermarkets too much, too frequent discounts, but also on the brand image constitutes some damage. Meanwhile, the brand is often in high-end luxury goods or goods, they are not suitable for sale in supermarkets.

Through the 100 valid questionnaires analysis results are shown (the horizontal axis represents the brand category, the vertical axis represents that the supermarkets for the sale of clothing brands such trips).As is shown figure 6 Supermarketswhich brand fit to buy.

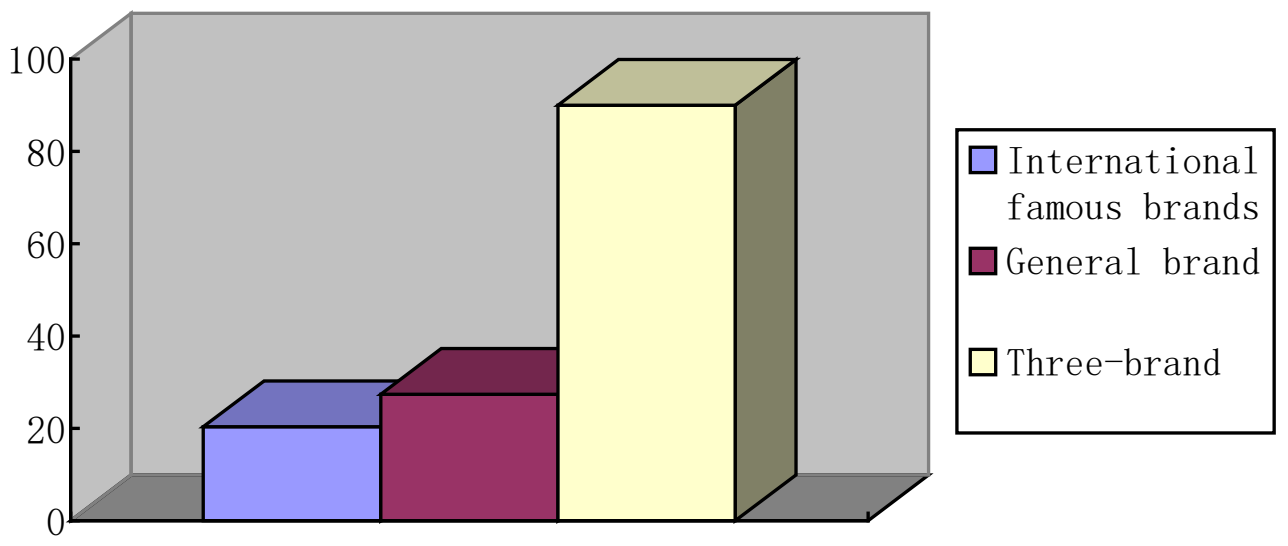

Fig.6 Supermarket switch brand fit to buy

Based on the above analysis and research shows that the city for business part of the general well-known brand and most of the third-tier brands.

Ordinary clothing store sales model characteristics. Apparel industry product variety, brand and manufacturing companies, and this has caused a large number of retail organizations of different styles, especially in ordinary clothing store type and quantity as the most, decorating store image and layout vary widely, with other types of compared to clothing retail organization, ordinary clothing store is not fixed operating a brand or several brands, either chain enterprises, self-employed can also be a single store. Lack of standardized management, the target group is mobile customers, are widely distributed. As is shown in figure 7 Ordinary clothing store.

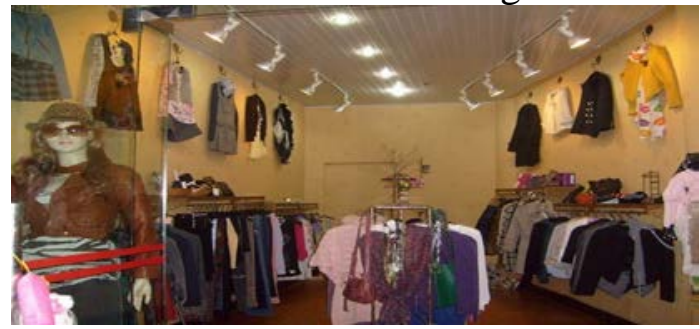

Fig.7 Ordinary clothing store

Apparel industry product variety, brand and manufacturing companies, and this has caused a large number of retail organizations of different styles, especially in ordinary clothing store type and quantity as the most, decorating store image and layout vary widely, with other types of compared to clothing retail organization, ordinary clothing store is not fixed operating a brand or several brands, either chain enterprises, self-employed can also be a single store. Lack of standardized management, the target group is mobile customers, are widely distributed.

Mutual adaptability of ordinary clothing store and clothing products most ordinary clothing store crowded cluttered, decorating layout and overall sense of a lack of coordination, as well as its mediocre pre-sale and after-sales service, determine the most ordinary clothing store not purchase goods for sale with more features upscale, high-end clothing, general clothing more suitable for mid-range, sales of low-end goods.

On the one hand, ordinary clothing store spread to the brand image and brand culture is difficult to play a positive role, a single promotional tool, is not conducive to the promotion and display brand clothing; on the other hand, since the clothing product counterfeiting famous, well-known brands the phenomenon is quite common in the current 
Market, the possibility of counterfeit clothing ordinary clothing store to buy a big, after-sales service quality assurance lack of consumer confidence but these fickle clothing store, they do not have the ability and charisma to attract well-known, well-known brand clothing consumers.

Ordinary clothing store target consumers located in the flow of customers, they do not have significant brand loyalty and brand preference. Customers with the investigation into ordinary clothing store $92 \%$ in advance and did not want to buy what brand good, after you buy clothing, there are up to $78 \%$ of customers do not know what brand to buy their own. So, to sum up, the general line of clothing is more suitable for the sale of three brands of clothing.

Categories Clothing wholesalers and Adaptability. Wholesalers do not deal directly with consumers, only play the role of setter; less attention wholesalers promotion, atmosphere and shop and store image, because their trading partners are not final consumers. Wholesalers large number of transactions many kinds of products. Wholesalers to retailers to use their network dissemination of corporate marketing philosophy, management policies, brand image and product features, which is conducive to attracting retailers to join. Purchasing and repairing a variety of goods, for the convenience of the retailer's unified purchase.

Types of channels and their respective levels of features and adaptability. This is a longitudinal analysis of marketing channel mode, the channel level composed of a different number of varying lengths marketing channels. According to different levels of channels, marketing channels can be divided into three categories of clothing: zero level channels, primary channels, secondary channels and tertiary channels.

\section{"HeiLan Home" to buy clothing from sales model analysis}

HeiLan Home clothing brand is launched in September 2002, in 2005, the domestic market experienced negative growth trend male suit, Sea Orchid House has continuous profit.

Sea Orchid House brand retail model. HeiLan Home is to use the SPA brand model of the Chinese garment industry first enterprise in the strict sense.

Pricing strategy and innovation. HeiLan Home for product positioning is "high quality, price." HeiLan Home agreed to the price, no discount sale reduction marketing model to enhance the brand integrity, ensure that obsolete leading fashion brand.

Store expansion establishment of sales network, HeiLan Home currently has 400 branches in New York, he sent a Paris, Milan, Tokyo, Hong Kong and established more than 20 overseas branches and information station.

The benefit of SPA is to reduce the number of intermediate links, shorten the supply chain length, and realize the rapid supply of clothing market through innovative methods and processes. The distribution pattern of the traditional clothing enterprises is the pasture, the wool wholesalers fabric manufacturers - clothing wholesalers - clothing market. In the traditional mode of circulation, because there are many layers, it is difficult to control the cost and quality of the products. The circulation pattern of the HeiLan Home is pasture- factory -store.

HeiLan Home exclusive industry retail model. HeiLan Home is the "McDonald" model, this model can reflect the unity of the home of the sea, the price, management, procurement, distribution, decoration and other national unified chain management mode. HeiLan Home according to the male way of shopping, so the only created "without interference, self-service" evaluative model, and discards the shopping guide mode. Consumers can according to their height, body clothes optional.

\section{Clothing sales channel model summary}

The reason of a brand marketing is success, because the choice of a suitable way of development, it is based on its own characteristics and want to build the type, select the appropriate marketing approach, the correct understanding of brand positioning, and fully learn from the international well-known brand marketing model and consider their own situation.

This paper describes the marketing channel theory, summarizes the basic characteristics of clothing products and clothing consumption, analyzes the elements of classification channel mode, 
each element has its own products and brands adaptability. Make channel selection and the establishment is not a simple mix of process mode, garment enterprise marketing channel mode according to their own situation to choose the right, only depending on different clothing products, brands and corporate marketing conditions, choose a different fashion marketing channels mode, is the most successful marketing decisions.

Establish apparel marketing channel model is not a simple thing, only on the basis of the environment has changed, based on the specific clothing products, brands and corporate existing by marketing capabilities and resources of the decision of marketing conditions, timely marketing channel mode reform and reconstruction, in order to achieve effective distribution and economic interests of the enterprise products.

\section{Reference}

[1] Sen S, Majumder S. Relative efficiency in adaptation to pro-competitive environment: unorganized Indian textile and garments enterprises. Journal of Rural and Industrial Development, 2015, 2(2).

[2] Yeh C, Lee Y. Construction of speed-to-market supply chain management model for garment industry. Journal of Manufacturing Technology Management, 2014, 25(5): 734-746.

[3] Song H, Fan C. Research of the Typical Supply Chain Management Models of the Garment Industry in China. International Journal of Business Administration, 2012, 3(5): p78.

[4] Sen S, Majumder S. Relative efficiency in adaptation to pro-competitive environment: unorganized Indian textile and garments enterprises. Journal of Rural and Industrial Development, 2015, 2(2).

[5] Liedholm C E, Mead D C. Small enterprises and economic development: the dynamics of micro and small enterprises. Routledge, 2013.

[6] Chen J W, Liu H Y, Shang L, et al. Study of the Garment Enterprises Diversification Development Trend Based on the Long Tail. Journal of Qingdao University(Engineering \& Technology edition), 2013, 28(1): 60-64.

[7] Li Y, Wang T. Study on enterprise microblog marketing SWOT analysis and marketing strategy[C]//Proceedings of the 2012 International Conference on Cybernetics and Informatics. Springer New York, 2014: 897-904.

[8] Liu H, Liang S, Hu S. Research on the Custom Pricing Model of Online Retail Clothing. Journal of Business Administration Research, 2014, 3(2): p28.

[9] Butollo F. Growing against the odds: government agency and strategic recoupling as sources of competitiveness in the garment industry of the Pearl River Delta. Cambridge Journal of Regions, Economy and Society, 2015: rsv020.

[10] Handbook on electronic commerce[M]. Springer Science \& Business Media, 2012.

[11] Abebe G, Sonobe T. Management Practices, Self-Selection into Management Training Participation, and Training Effects in the Garment Industry in Ethiopia. National Graduate Institute for Policy Studies, 2012.

[12] Nguyen H. Impact of Relationship Marketing on Export Performance: Empirical Study in Vietnamese Garment Enterprises. International Business Research, 2012, 5(12): p133.

[13] Chopra R, Sharma H. Corporate to Cooperative Entrepreneurial Leadership in Emerging Economy-Lessons from Indian Enterprises. Journal of Organisation and Human Behaviour, 2012, 1(4): 12. 
[14] Tseng S C, Hung S W. A strategic decision-making model considering the social costs of carbon dioxide emissions for sustainable supply chain management. Journal of environmental management, 2014, 133: 315-322.

[15] Zhang T, Ling J, Zhang S, et al. Ecology dynamics model on Chinese apparel industry cluster. The Journal of The Textile Institute, 2014, 105(8): 867-877. 